\title{
WPROWADZENIE DO POSTĘPOWANIA PRZYGOTOWAWCZEGO MATERIALÓW Z CZYNNOŚCI OPERACYJNO- -ROZPOZNAWCZYCH ZAWIERAJĄCYCH TAJEMNICE ZAWODOWE W ŚWIETLE PRZEPISÓW INTERTEMPORALNYCH
}

\begin{abstract}
Streszczenie. Pozyskiwanie dowodów w toku postepowania karnego wiąże się z szeregiem czynności, które winny zostać wykonane tak, aby były one prawnie dopuszczalne. Szczególne unormowania ustawodawca przewidział w zakresie pozyskiwania dowodów poza postępowaniem karnym. W toku czynności operacyjno-rozpoznawczych prowadzonych przez organy szczególne możliwe jest dokonywanie kontroli między innymi rozmów telefonicznych. Wprowadzenie dowodów z tych nagrań uregulowane jest w sposób szczególny. W pewnych sytuacjach ustawodawca przewidział dodatkowe obostrzenia w zakresie uzyskiwania dowodów wówczas, gdy dotyczy to tajemnic zawodowych szczególnie chronionych - art. 180 § 2 k.p.k. Niniejsze opracowanie przedstawia wskazaną problematykę.
\end{abstract}

Słowa kluczowe: proces karny, przesłanki procesowe, podsłuch, tajemnice zawodowe.

Pomimo dokonania szeregu nowelizacji przepisów prawa procesowego, w tym dotyczących ochrony tajemnicy zawodowej, w dalszym ciągu słuszne jest stwierdzenie wyrażane w literaturze (Rusinek 2007) ${ }^{1}$, że ustawa procesowa chroni tajemnicę zawodową w przypadku świadków (art. 180 k.p.k.) oraz dokumentów (art. 225 i art. 226 k.p.k.), a przepisy dotyczące procesowej kontroli i utrwalania rozmów pomijają ten problem milczeniem. Całkowicie poza zakresem niniejszego opracowania są kwestie prawnej dopuszczalności stosowania podsłuchu i innych metod pozyskiwania dokumentów od ich depozytariuszy będących osobami chronionymi zakazami dowodowymi z zakresu ochrony tajemnicy zawodowej, gdyż głównym założeniem jest przedstawienie sposobu wprowadzenia materiałów uzyskanych z szeroko pojętych czynności operacyjno-rozpoznawczych. Tym niemniej niezbędne jest wskazanie, jaki jest zakres ochrony informacji uzyskanych tą drogą, w szczególności w ujęciu intertemporalnym. Należy poczynić zastrzeżenie, że zmiany ustawowe dotyczyły szeregu ustaw, o czym będzie jeszcze mowa poniżej, tym niemniej główne rozważania będą prowadzone w oparciu o ustawę o CBA. Rozwiązania pozostałych ustaw są analogiczne w głównych założeniach.

* Uniwersytet Łódzki, Wydział Prawa i Administracji, Katedra Postępowania Karnego i Kryminalistyki, kurowski1977@gmail.com.

${ }^{1}$ Odwołania uczynione w niniejszym opracowaniu dokonano na podstawie wersji elektronicznej dostępnej w programie LEX. 
Ponieważ prezentowane w tym opracowaniu tezy nie będą dotyczyły zakresu tzw. zgody pierwotnej, uznałem, że nie jest niezbędne prezentowanie poszczególnych ustaw, a wystarczające będzie omówienie rozwiązań szczególnych jednej ustawy.

Przed wejściem w życie ustawy z dnia 15 stycznia 2016 r. o zmianie ustawy o Policji oraz niektórych innych ustaw (Dz. U. 2016, poz. 147)² zarówno na gruncie podsłuchu procesowego (rozdział 26 Kodeksu postępowania karnego), jak i regulacji tzw. podsłuchu operacyjnego (pozaprocesowego/przedprocesowego) (Eichstaedt 2003, 28) w ramach poszczególnych ustaw policyjnych ${ }^{3}$ brak $^{2}$ było instytucji szczególnych dotyczących modelu wprowadzenia dowodu objętego ochroną wynikającą z tajemnicy zawodowej do postępowania karnego. Ówczesny model - zgodnie z zapatrywaniem doktryny i piśmiennictwa (Lodziana 2013, 148-156) - generalnie zakładał konieczność przekazania prokuratorowi całego zgromadzonego materiału dowodowego, który jednak w pewnych sytuacjach nie mógł być wykorzystany (brak zgody następczej) ${ }^{4}$, co nie zmienia faktu, że materiały udostępnione mogły zawierać treści objęte tajemnicami zawodowymi. Uznawano wówczas, że dowodem z takiej czynności jest dokument (Rusinek 2007; Kurowski 2015, 603) w postaci jej nagrania (rejestracji) ${ }^{5}$. Przyjmowanie konstrukcji dokumentu argumentowane było poprzez odwołanie się do sposobu przeprowadzenia dowodu z czynności operacyjnej na rozprawie głównej, a w szczególności możliwości odczytania tak wytworzonych materiałów w toku procesu jako dokumentów. Możliwość taka przewidziana była poprzez odwołanie do art. $393 \S 1$ k.p.k. jako podstawy prawnej. Odwołanie to wprowadzały i wprowadzają przepisy art. 19 ust. 15 ustawy o Policji, art. 9e ust. 16 ustawy o Straży

${ }^{2}$ Mowa tu o dużej nowelizacji czynności operacyjno-rozpoznawczych dokonanej w szeregu ustaw, a wynikającej z konieczności uwzględnienia zapatrywań prawnych Trybunału Konstytucyjnego.

${ }^{3}$ Mowa tu o regulacjach, które wprowadzały:

1) ustawa z dnia 6 czerwca 1990 r. o Policji (Dz. U. 2015, poz. 355);

2) ustawa z dnia 12 października 1990 r. o Straży Granicznej (Dz. U. 2014, poz. 1402 t.j.);

3) ustawa z dnia 28 września 1991 r. o kontroli skarbowej (Dz. U. 2015, poz. 553);

4) ustawa z dnia 24 sierpnia 2001 r. o Żandarmerii Wojskowej i wojskowych organach porządkowych (Dz. U. 2016, poz. 96);

5) ustawa z dnia 24 maja 2002 r. o Agencji Bezpieczeństwa Wewnętrznego i Agencji Wywiadu (Dz. U. 2015, poz. 1929 t.j.);

6) ustawa z dnia 9 czerwca 2006 r. o Służbie Kontrwywiadu Wojskowego oraz Służbie Wywiadu Wojskowego (Dz. U. 2014, poz. 253);

7) ustawa z dnia 6 czerwca 2006 r. o Centralnym Biurze Antykorupcyjnym (Dz. U. 2014, poz. 1411).

${ }^{4}$ Chodzi tu oczywiście o brak zgody następczej sądu z uwagi na odmowę jej udzielenia, jak również z uwag na niewystąpienie $\mathrm{z}$ takim wnioskiem przez organy uprawnione.

${ }^{5}$ Problematykę uznawania nagrania dźwięku i obrazu lub tylko jednego z nich jako dokumentu nie jest tak oczywista, jak przedstawia ją M. Rusinek. Wskazać tu bowiem należy, że w pewnych sytuacjach nagranie stanowić może dowód rzeczowy, a w pewnych jest dokumentem (por. Kurowski 2015, 603 i przywołana tam literatura). 
Granicznej, art. 17 ust. 15 ustawy o Centralnym Biurze Antykorupcyjnym i art. 27 ust. 15 ustawy o Agencji Bezpieczeństwa Wewnętrznego i Agencji Wywiadu.

W zakresie podsłuchu procesowego, w piśmiennictwie (Musialik 1998, 89) słusznie wskazywano, że wprowadzenie do procesu materiałów zawierających tajemnice zawodowe musi nastąpić w zgodzie z art. 226 k.p.k., choć wykładnia literalna przepisu nie dawała podstaw do takiego wnioskowania. Do takiej konstatacji skłaniało jednak wyżej już wspomniane pojęcie dowodu. W zakresie tego zagadnienia zasadnie podkreślano (Dudka 1998, 79-80), iż nie istnieje zakaz pozyskiwania dowodu w postaci nagrania pochodzącego z kontroli procesowej od osób chronionych określonymi zakazami dowodowymi ${ }^{6}$, ale już uzyskany zapis musi być stosownie chroniony i wprowadzony do postępowania zgodnie $\mathrm{z}$ określonymi regułami.

Pomimo powyższej opisanych rozwiązań wskazujących na możliwości wykorzystania dowodu z kontroli operacyjnej w procesie karnym z odwołaniem się do art. 226 k.p.k. (Rusinek 2007), Prokurator Generalny oraz Rzecznik Praw Obywatelskich wystąpili do Trybunału Konstytucyjnego o zbadanie konstytucyjności przepisów ustaw szczególnych ${ }^{7}$ regulujących możliwość prowadzenia kontroli operacyjnej w zakresie gwarancyjnym związanym z ochroną tajemnicy zawodowej ${ }^{8}$. W wyroku z dnia 30 lipca 2014 r. (K 23/11 - Dz. U. 2014, poz. 1055) Trybunał wskazał, że - w zakresie, w jakim (przepisy ustaw policyjnych - przyp. M. K.) nie przewidują gwarancji niezwłocznego, komisyjnego i protokolarnego zniszczenia materiałów zawierających informacje objęte zakazami dowodowymi, co do których sąd nie uchylił tajemnicy zawodowej bądź uchylenie było niedopuszczalne, są niezgodne $\mathrm{z}$ art. 42 ust. 2 , art. 47 , art. 49, art. 51 ust. 2 i art. 54 ust. $1 \mathrm{w}$ związku $\mathrm{z}$ art. 31 ust. 3 Konstytucji. Konsekwencją tego orzeczenia była konieczność dokonania zmiany ustawowej w zakresie regulacji dotyczących kontroli operacyjnej, a de facto, odnośnie sposobu postępowania z materiałami uzyskanymi w jej toku? Taka zmiana została wprowadzona do porządku prawnego ustawą z dnia 15 stycznia 2016 r. o zmianie ustawy o Policji oraz niektórych innych ustaw (Dz. U. 2016, poz. 147$)^{10}$. Nowelizacja prawa policyjnego dotknęła poza wskazanym obszarem

${ }^{6}$ Wskazane rozwiązania zostaną przedstawione w dalszej części opracowania.

${ }^{7}$ Wymieniono powołane ustawy w przyp. 4.

8 Wskazać należy, iż zakres wniosku o zbadanie konstytucyjności wymienionych ustaw obejmował znacznie szerszy zakres problematyki niż jedynie samą kwestię związaną z ochroną tajemnicy zawodowej, dotyczył on bowiem głównie problematyki dopuszczalności samych czynności operacyjno-rozpoznawczych, ich zakresu, dopuszczalnej ingerencji w sferę wolności obywatelskich czy konieczności poinformowania osoby, wobec której stosowane były takie techniki o fakcie takiej ingerencji.

${ }^{9}$ Oczywiście zastrzeżenia Trybunału skupiały się również na innych aspektach czynności operacyjno-rozpoznawczych, np. kwestii ich dookreślenia ustawowego sposobu prowadzenia czynności, uregulowaniach kontrolnych, ograniczeniu czasu stosowania czynności itp. Jednakże pełne wymienienie ich w niniejszym opracowaniu nie jest celowe.

${ }^{10}$ Podkreślić należy, iż zmiana dokonana powołaną ustawą nie odpowiada oczekiwaniom Trybunału Konstytucyjnego, albowiem nie zostały wykonane wszystkie zalecenia wynikające z powolanego wyroku. 
również innych kwestii, co było konieczne również z uwagi na treść powołanego powyżej wyroku Trybunału. Jak wynika z uzasadnienia wprowadzanej ustawy, jej głównym zadaniem było dostosowanie rozwiązań kontroli operacyjnej do wymogów wskazanych w powołanym orzeczeniu. Już w tym miejscu zaznaczyć należy, iż zmiana dokonana w wyniku wykonania wyroku Trybunału Konstytucyjnego funkcjonowała w modelu zapewniającym pełną kontrolę sądową nad czynnościami, w szczególności to ten organ wyrażał tzw. zgodę następczą, kiedy to stosowne przepisy przewidywały zarówno ograniczenie czasowe wykorzystania materiałów, jak i decyzję w tym przedmiocie podejmował sąd.

Podstawowym problemem, który pojawia się przy interpretacji przepisów wskazanej ustawy w świetle norm intertemporalnych, jest konieczność ustalenia, że:

- ustawa zmieniająca przepisy ustaw policyjnych w zakresie czynności operacyjno-rozpoznawczych weszła w życie w dniu 7 lutego 2016 r., a zatem wówczas, gdy obowiązywały jeszcze przepisy intertemporalne ustawy z dnia 27 września 2013 r. o zmianie ustawy Kodeks postępowania karnego oraz niektórych innych ustaw (Dz. U. 2013, poz. 1247 z późn. zm.), która to ustawa wprowadzała tzw. ,szeroką kontradyktoryjność” (Kurowski 2015);

- kolejna ustawa, a mianowicie akt prawny z dnia 11 marca 2016 r. o zmianie ustawy Kodeks postępowania karnego oraz niektórych innych ustaw (Dz. U. 2016, poz. 437) ${ }^{11}$ wprowadza nowy model zgód następczych zarówno w odniesieniu do kontroli procesowej, jak i operacyjnej, a co jeszcze ważniejsze - zmienia normy intertemporalne (oczywiście nie wszystkie).

Taki układ aktów ustawodawczych, zasadniczo rozbieżnych w zakresie uregulowania podstawowych aspektów omawianej instytucji, powoduje, że powstawać może wiele wątpliwości w zakresie interpretacji możliwości wykorzystania i trybu wprowadzenia do procesu dowodów. Nie jest wykluczone, że kontrola operacyjna zainicjowana została przed wejściem w życie ustawy z 15 stycznia 2016 r., a zakończyła się już po 15 kwietnia 2016 r. (tj. po wejściu w życie nowelizacji z marca 2016 r.). Dodatkowo, z uwagi na brzmienie przepisów przejściowych wskazać należy, iż niezbędne jest odniesienie się do następującego układu faktycznego, a mianowicie: zakończonych już kontroli operacyjnych przed wejściem w życie ustawy z 15 stycznia 2016 r. oraz takiej, która zakończyła się w okresie pomiędzy 7 lutego a 15 kwietnia 2016 r. Wskazać tu należy, iż dodatkowym elementem niezbędnym dla interpretacji jest wskazanie, że kluczowe zmiany w wykonaniu wyroku Trybunału Konstytucyjnego nie objęły instytucji - tzw. kontrolowanego wręczenia korzyści - czyli dokonania w sposób niejawny nabycia, zbycia lub przejęcia przedmiotów pochodzących z przestępstwa, ulegających przepadkowi albo których wytwarzanie, posiadanie, przewożenie lub którymi obrót są zabronione, a także przyjęcia lub wręczenia korzyści majątkowej (art. 19a

${ }^{11}$ Zmiana w ustawach policyjnych następuje niejako przy okazji nowelizacji całej procedury karnej. 
ustawy o Policji). Szczególne znaczenie kwestia uregulowania tej problematyki ma na gruncie ustaw szczególnych (zobacz odpowiednio np. ustawa o CBA - art. 17 ustawy w zakresie czynności operacyjnych i art. 19 w zakresie kontrolowanego wręczenia korzyści). Tym samym zgromadzony materiał dowodowy obejmować może zarówno czynności realizowane w ramach kontroli operacyjnej, jak i innych dopuszczalnych metod.

Konstrukcja rozwiązań poszczególnych ustaw w swoich głównych instytucjach w zakresie omawianej problematyki jest dość zbieżna. Generalnie bowiem istnieje podział na ogólną kontrolę operacyjną oraz innego rodzaju czynności szczególne (np. kontrolowane wręczenie korzyści, przesyłkę kontrolowaną itp.). W dalszej części opracowania rozważania prowadzone będą w oparciu o normy prawne zawarte w ustawie o Centralnym Biurze Antykorupcyjnym.

Jak już podkreślano, ustawodawca dokonał znaczącego przesunięcia miejsca regulacji sposobów prowadzenia czynności operacyjno-rozpoznawczych, albowiem z uregulowań rozporządzenia wykonawczego zostały one bezpośrednio przeniesione do ustawy. Zgodnie z art. 17 ust. 5 ustawy o CBA - kontrola operacyjna prowadzona jest niejawnie i polega na:

1) uzyskiwaniu i utrwalaniu treści rozmów prowadzonych przy użyciu środków technicznych, w tym za pomocą sieci telekomunikacyjnych;

2) uzyskiwaniu i utrwalaniu obrazu lub dźwięku osób z pomieszczeń, środków transportu lub miejsc innych niż miejsca publiczne;

3) uzyskiwaniu i utrwalaniu treści korespondencji, w tym korespondencji prowadzonej za pomocą środków komunikacji elektronicznej;

4) uzyskiwaniu i utrwalaniu danych zawartych w informatycznych nośnikach danych, telekomunikacyjnych urządzeniach końcowych, systemach informatycznych i teleinformatycznych;

5) uzyskiwaniu dostępu i kontroli zawartości przesyłek.

W takim ujęciu zatem czynności polegające na dokonaniu w sposób niejawny nabycia lub przejęcia przedmiotów pochodzących z przestępstwa, ulegających przepadkowi albo których wytwarzanie, posiadanie, przewożenie lub obrót są zabronione, a także na przyjęciu lub wręczeniu korzyści majątkowej (art. 19 ust. 1 ustawy o CBA) nie mieszczą się w katalogu czynności opisanych w art. 17 powołanej ustawy. Tym samym w postępowaniu karnym występować mogą dwie zasadnicze grupy materiałów niejawnych - te, które zostały wytworzone w drodze kontroli operacyjnej oraz takie, które wprowadzono w wyniku innych metod. W świetle obowiązującego obecnie ustawodawstwa (gdyby czynności procesowe prowadzone były w oparciu o przepisy obecnie obowiązującej ustawy o CBA - zarówno z wykorzystaniem art. 17, jak i 19 ustawy) w sytuacji stwierdzenia, że uzyskane materiały zawierają tajemnicę zawodową, tj. adwokacką, o której mowa $\mathrm{w}$ art. $180 \S 2$ k.p.k., powstaje swoisty dualizm prawny w zakresie dalszego trybu postępowania $\mathrm{z}$ tymi materiałami. 
W sytuacji bowiem uzyskania tych materiałów w trybie przewidzianym $\mathrm{w}$ art. 17 ustawy o CBA dalszą drogę wprowadzenia ich do postępowania reguluje art. 17 ust. $15 \mathrm{~g}$ i następne powołanej ustawy. Wówczas to, zgodnie z normami prawnymi wprowadzonymi na skutek wykonania wyroku Trybunału Konstytucyjnego, Prokurator Generalny niezwłocznie po otrzymaniu materiałów kieruje je do sądu, który zarządził kontrolę operacyjną albo wyraził na nią zgodę w trybie określonym w ust. 3, wraz z wnioskiem o:

1) stwierdzenie, które $z$ przekazanych materiałów zawierają informacje, o których mowa w ust. 15 f pkt 2 (tajemnice zawodowe);

2) dopuszczenie do wykorzystania w postępowaniu karnym materiałów zawierających informacje stanowiące tajemnice związane $\mathrm{z}$ wykonywaniem zawodu lub funkcji, o których mowa w art. $180 \S 2$ k.p.k. Sąd, niezwłocznie po złożeniu wniosku przez Prokuratora Generalnego, wydaje postanowienie o dopuszczeniu do wykorzystania $\mathrm{w}$ postępowaniu karnym materiałów, o których mowa w ust. $15 \mathrm{~g}$ pkt 2 , gdy jest to niezbędne dla dobra wymiaru sprawiedliwości, a okoliczność nie może być ustalona na podstawie innego dowodu, a także zarządza niezwłoczne zniszczenie materiałów, których wykorzystanie w postępowaniu karnym jest niedopuszczalne.

Natomiast w sytuacji, gdyby działania operacyjno-rozpoznawcze obejmowały inne dopuszczalne przez prawo czynności dowodowe (np. z art. 19 ustawy o CBA), wówczas jak się wydaje, wobec braku odpowiedniego uregulowania w art. 19 ustawy o CBA w zakresie stosowania odpowiednio przepisów art. 17 tej ustawy, zastosowanie znajdą przepisy art. 168b k.p.k. (mowa tu o braku okoliczności objętych tajemnicą i jednoczesnym stwierdzeniu, że np. ujawniono czyny nieobjęte zgodą pierwotną lub osoby nieobjęte taką zgodą). Natomiast w sytuacji, gdyby materiały te zawierały jednak tajemnice, o których mowa w art. 226 k.p.k. w zw. z art. $180 \S 2$ k.p.k., wydaje się, że przepis ten (art. 226 k.p.k.) jako lex specialis wobec art. 168b k.p.k. musiałby tu znaleźć zastosowanie. Zatem wówczas uprawnionym byłby prokurator (bez zastrzeżenia, że musi to być Prokurator Generalny), a właściwym do rozpoznania wniosku - sąd powołany do rozpoznania sprawy w I instancji (art. 329 k.p.k.) Już zatem powyższe budzić może pewne wątpliwości, a mianowicie - jaki jest powód ustawowy odmiennego uregulowania postępowania $\mathrm{z}$ materiałami w zależności od formy prowadzenia tych czynności.

Podkreślić tu należy, iż co więcej - zgodnie z art. 20 ustawy o CBA - podczas prowadzenia czynności w warunkach art. 19 ustawy o CBA może być stosowana kontrola na zasadach określonych $\mathrm{w}$ art. 17 ustawy. W takiej zatem sytuacji powstaje zasadnicze pytanie, jaki jest właściwy tryb postępowania dla wprowadzenia wskazanych dowodów do procesu karnego oraz czy sformułowanie ,na zasadach art. 17" oznacza również przeniesienie na grunt art. 19 trybu uzyskiwania zgody sądu na wykorzystanie wskazanych materiałów? 
W komentarzu autorstwa Hoca i Szustakiewicza $(2012,20)^{12}$ poruszono wskazany problem art. 20 ustawy o CBA. Jak wskazują autorzy: „Wydaje się, że zamiarem ustawodawcy było umożliwienie dokumentowania np. kontrolowanego przyjęcia lub wręczenia korzyści majątkowej za pomocą urządzeń służących do rejestracji obrazu i dźwięku. Ustawodawca, używając określenia «na zasadach określonych $\mathrm{w}$ art. 17», mógł mieć na myśli sposób postępowania $\mathrm{z}$ materiałami uzyskanymi lub ich brakiem w ramach art. 19 ustawy o CBA, podobnie jak $\mathrm{w}$ art. 17, a nie tryb ich zarządzenia, czyli zarządzenie kontroli operacyjnej przez sąd na pisemny wniosek Szefa CBA, złożony po uzyskaniu pisemnej zgody Prokuratora Generalnego. Przyjęcie tej wykładni nie wyklucza możliwości stosowania kontroli operacyjnej, o której mowa w art. 17 ustawy o CBA". W takim ujęciu można byłoby przyjąć, że pozyskiwanie zgody na wykorzystanie materiałów utrwalonych powinno zatem zawsze następować w trybie art. 17 ustawy o CBA. Jest to jednak jedynie jedna z możliwych wykładni przepisu art. 20 ustawy o CBA, albowiem ustawodawca w art. 17 nie wymienia w ogóle możliwości stosowania rejestracji ukierunkowanej na konkretną osobę podczas wręczania/ przyjmowania korzyści, a wskazuje jedynie w art. 15 ust. 5 pkt 2 na ogólne uzyskiwanie i utrwalanie obrazu i dźwięku osób z pomieszczeń, środków transportu lub miejsc innych niż publiczne. W tym zatem zakresie przepis budzi poważne wątpliwości co do trybu uzyskiwania zgody sądu. W szczególności, jak w powyżej powołanym piśmiennictwie, wskazuje się na stwierdzenie „mógł mieć na myśli”, a brak jest kategorycznych stwierdzeń. Zatem, jak wskazano, można przyjąć, że wówczas, gdy czynności prowadzone w trybie art. 19 ustawy o CBA rejestrowane są przy wykorzystaniu metod $\mathrm{z}$ art. 17 tej ustawy, stosuje się tryb tam przewidziany, w pozostałych zaś sytuacjach stosuje się tryb z art. 226 k.p.k. Tezę taką wspiera dodatkowo okoliczność, iż na podstawie delegacji ustawowej zawartej w art. 20 ustawy o CBA Prezes Rady Ministrów w dniu 7 września 2006 r. wydał rozporządzenie w sprawie sposobu przeprowadzania przez Centralne Biuro Antykorupcyjne i dokumentowania czynności polegających na dokonaniu w sposób niejawny nabycia lub przejęcia przedmiotów pochodzących z przestępstwa, ulegających przepadkowi albo których wytwarzanie, posiadanie, przewożenie lub którymi obrót są zabronione, a także na przyjęciu lub wręczeniu korzyści majątkowej (Dz. U. 2006, Nr 165, poz. 1172). Przedmiotowy akt prawny nie został do dnia dzisiejszego uchylony. Zgodnie z § 4 wskazanego aktu prawnego między innymi dokumentację czynności stanowią także materiały uzyskane podczas ich stosowania, a w szczególności nośniki zawierające zapisy z rejestracji obrazu lub dźwięku oraz kopie wykonane z tych nośników, a także dokumenty sporządzone na podstawie informacji utrwalonych na nośnikach.

${ }^{12}$ Odwołanie dotyczy numeru komentowanego przepisu - a nie strony publikacji - jest bowiem do wersji elektronicznej. 
Wydaje się zatem, że w sytuacji stosowania równolegle kontroli operacyjnej w trybie art. 17 ustawy o CBA i wręczenia korzyści w trybie art. 19 tej ustawy, wówczas gdy dla dokumentowania czynności z art. 19 wykorzystywane są nazwane czynności, enumeratywnie wymienione w art. 17 ust. 5 ustawy o CBA, dla możliwości wykorzystania ich $\mathrm{w}$ procesie $\mathrm{w}$ zakresie, w jakim obejmują tajemnice zawodowe, należy wyczerpać drogę określoną w art. 17 ustawy o CBA. W pozostałych zaś sytuacjach zastosowanie winien znaleźć art. 226 k.p.k.

Jak powyżej podkreślono, są to uregulowania obecnie obowiązujące i już one budzą poważną wątpliwość. Dodatkowo, na gruncie niniejszego postępowania należy uwzględnić problematykę norm intertemporalnych.

Zapisy art. 17 ustawy o CBA, w brzmieniu obecnym, wprowadzono do porządku prawnego na skutek wykonania wyroku Trybunału Konstytucyjnego z dnia 30 lipca 2014 r. (K 23/11) w dniu 8 lutego 2016 r. Obowiązywał wówczas tryb art. 226 k.p.k., w brzmieniu dotychczasowym, a zatem przewidujący tryb wprowadzenia do postępowania dokumentów zawierających tajemnice określone w art. $180 \S 2$ k.p.k. (Grabowska-Moroz 2016, 34-36). Wobec powyższego niewątpliwie art. 17 ustawy o CBA w zakresie, w jakim przewiduje on odmienny od wskazanego w kodeksie tryb postępowania, należy uznać za instytucję szczególną wobec normy ogólnej z art. 226 k.p.k. W art. 13 ustawy z dnia 15 stycznia 2016 r. o zmianie ustawy o Policji oraz niektórych innych ustaw wskazano, że art. 17 ust. 15f i następne stosuje się do kontroli operacyjnej, która była prowadzona przed dniem wejścia w życie ustawy i nie została zakończona przed tym terminem. Powyższa norma intertemporalna powiązana zatem z zasadami ogólnymi stosowania przepisów prawa procesowego $\mathrm{w}$ dacie ich obowiązywania pozwala na stwierdzenie, że norma w nowym brzmieniu stosowana jest do dwóch stanów prawnych tj.:

- wówczas, gdy kontrola operacyjna została wszczęta po dacie wejścia w życie ustawy;

- wówczas, gdy kontrola została zakończona przed dniem wejścia w życie ustawy.

W tym ostatnim jednak przypadku z zastrzeżeniem, że gdy wyczerpano dopuszczalne metody wprowadzenia dowodów do postępowania (czyli drogę określoną w art. 226 k.p.k.), czynność taka jest ważna. W innej sytuacji, a zatem gdy przed wejściem w życie ustawy, o której mowa powyżej, czynności te nie zostały jednak dokonane, a kontrola była już zakończona, winien znaleźć zastosowanie przepis art. 17 ustawy o CBA, gdy mowa o czynnościach prowadzonych w jej trybie. Wskazać tu należy, iż ustawę z dnia 11 marca 2016 r. o zmianie ustawy Kodeks postępowania karnego oraz niektórych innych ustaw do porządku prawnego dodatkowo wprowadzono przepis art. 168b, dotyczący wprowadzania przez prokuratora (który zastąpił zgodę następczą sądu), jednak nie dotyczy on - jak się wydaje - czynów objętych tajemnicami. Kluczowe znaczenie ma tu jednak art. 24 (Augustyniak i in. 2016, 702) powołanej ustawy, który wskazuje, że postępowanie 
toczy się wedle przepisów nowych, jednakże należy dokonać czynności procesowych, które są wymagane według przepisów niniejszej ustawy, a które do dnia wejścia w życie niniejszej ustawy nie zostały dokonane. Wobec powyższego wydaje się koniecznym dokonanie czynności w trybie art. 17 ustawy o CBA.

Konkludując, rozwiązania ustaw szczególnych z punktu widzenia dóbr, jakich dotyczą, wymagają jednak ustawowego doprecyzowania i ujednolicenia uzyskiwania zgody następczej sądu. Słuszne jest rozwiązanie, zgodnie z którym kontrolę sprawuje tu sąd, niezrozumiałym jest jednak różnicowanie podmiotu wnioskującego o jej wyrażenie.

\section{BIBLIOGRAFIA}

Augustyniak, Barbara, Krzysztof Eichstaedt, Michał Kurowski, Dariusz Świecki (red). 2016. Kodeks postepowania karnego. Komentarz do zmian 2016. Warszawa: Wolters Kluwer.

Dudka, Katarzyna. 1998. Kontrola korespondencji i podstuch w polskim procesie karnym. Lublin: Wydawnictwo Uniwersytetu Marii Curie-Skłodowskiej.

Eichstaedt, Krzysztof. 2003. „Zarządzenie przez sąd kontroli operacyjnej w ujęciu procesowym”. Prokuratura i Prawo 9: 28-48.

Grabowska-Moroz, Barbara. 2016. „Glosa do wyroku TS z dnia 8 kwietnia 2014 r., C-293/12 i C-594/12 oraz do wyroku TK z dnia 30 lipca 2014 r., K 23/11". Europejski Przeglad Sadowy 1: 31-36.

Grzegorczyk, Tomasz. 2008, Kodeks postepowania karnego. Komentarz. Warszawa: LexisNexis.

Hoc, Stanisław, Przemysław Szustakiewicz. 2012. Ustawa o Centralnym Biurze Antykorupcyjnym. Komentarz. el/LEX.

Hofmański Piotr, Ryszard A. Stefański (red.). 2016. System Prawa Karnego Procesowego. Tom X. Postępowanie przygotowawcze, Warszawa: Wolters Kluwer.

Kurowski, Michał. 2015. Zagadnienia ogólne i postępowanie przygotowawcze, Kraków: Grupa Wydawnicza Lumina.

Łodziana, Tomasz. 2013. „Zgoda następcza na przeprowadzenie czynności operacyjnych”. Prokuratura i Prawo 3: 148-156.

Musialik, Grażyna. 1998. „Dopuszczalność stosowania podsłuchu telekomunikacyjnego w stosunku do osób zobowiązanych do zachowania tajemnicy zawodowej na gruncie Kodeksu postępowania karnego z 1997 r.". Palestra 11-12: 86-95.

Rusinek, Michał. 2007. Tajemnica zawodowa i jej ochrona w polskim procesie karnym. Warszawa: Oficyna (el/LEX rozdział 4.2.3. Kontrola i utrwalanie rozmów).

Stefański, Ryszard, Jerzy Bartoszewski, Lech Gardocki, Zbigniew Gostyński, Stanisław M. Przyjemski, Ryszard A. Stefański, Stanisław Zabłocki. 2004. Kodeks postępowania karnego. Komentarz, Warszawa: Wydawnictwo ABC. 


\title{
INTRODUCTION OF MATERIALS FROM OPERATIONAL AND RECONNAISSANCE ACTIVITIES CONTAINING PROFESSIONAL SECRETS DUE TO INTERTEMPORAL RULES INTO THE PREPARATORY PROCEEDINGS
}

\begin{abstract}
Obtaining evidence during criminal proceedings involves a number of activities that should be carried out by a prosecutor so that they are legally permissible. The legislator anticipated special provisions in the field of obtaining evidence outside criminal proceedings. In the course of the operational activities carried out by special bodies (Police) it is possible to control inter alia telephone calls. The introduction of evidence from these recordings is regulated in a special way. In certain situations, the legislator provided additional restrictions on obtaining evidence especially when it is connected with highly protected professional secrets - art. $180 \S 2$ of the [Polish] penal procedure code. This article outlines the mentioned issues.
\end{abstract}

Keywords: criminal proceedings, procedural conditions, wiretapping, professional secrets. 